\title{
COMMERCIAL SMALLHOLDER LAYING HENS: PRODUCTION EFFICIENCY AND INTENSITY OF INPUT USE ACCORDING TO PRODUCTION PHASE IN SOUTH SULAWESI, INDONESIA
}

\author{
Paly Muhammad Basir \\ Department of Animal Sciences, Faculty of Science and Technology, Alauddin State Islamic \\ University, Makassar, Indonesia \\ E-mail: basirpaly@gmail.com
}

\begin{abstract}
The study was aimed to analyse production efficiency and intensity of input use according to production phase in commercial smallholders laying hens (CSLH) in South Sulawesi, Indonesia in three consecutive months. Production phase was determined by the hens' age, i.e. 5-12 months in Phase I and 13-18 months in Phase II. Data were collected from a survey to 35 and 32 CSLH samples from Phase I and II, respectively. Daily egg production was calculated in percent (\%), the main ration and feed additive was expressed in Indonesian currency unit (IDR) and the labor and experience were stated in hour/day and year, respectively. Data were subject to Cobb-Douglass production function (CD) analysis using SPSS 16 software. Results showed that production efficiency of Phase I and II hit Increasing Return to Scale (IRT) and a 1\% proportional increase of total input would improve egg production in Phase I and II by $3.07 \%$ and $2.06 \%$, respectively $(>1 \%)$. Intercept of production function in Phase I (61.60) was higher than that of Phase II (52.60). The intensity of main ration in Phase I and II was still underutilized; therefore, increasing the input potentially improved egg production. The intensity of feed additive in Phase I was optimum but overutilized in Phase II. Labor and experience inputs were overutilized in both Phases. In conclusion, CSLH efficiency in Phase I and II in South Sulawesi was subject to optimization by increasing the main ration input and decreasing labor and working experience input.
\end{abstract}

\section{KEY WORDS}

Efficiency, production, input, underutilizise, intensive, overutilizise.

Studies on production efficiency and intensity of input use on commercial laying hens have been published. The area of the studies includes productivity and technical efficiency of poultry egg production in Nigeria (Ojo, 2003); technical effciency of poultry egg production in Ogun State (Yusuf and Malomo, 2007);productivity analysis of eggs production in Khorasan Razavi province (Mohaddes, 2009);technical efficiency of poultry production in Afijio Local Government Area of Oyo state (NigeriaAdesiyan and Israel, 2014); technical, allocative and economic efficiency of commercial poultry farms in Bangladesh (Begum et al, 2010); evaluation of technical and economic effciency of laying hen farms in Konya (Dogan et al, 2018) and stochastic frontier production function and efficiency status of poultry layer farms in Malaysia (Elpawati et al, 2018). From seven publications, not one is discussing or referring to production phase. Nevertheless, we appreciated the authors for investing and disseminating information on the efficiency of laying hens farm for further studies.

The production phase of laying hens is based on the age. From the perspective of nutrient demand, Leeson and Summers (2008) categorized production phase into three: Phase I (5-8 months), Phase II (8-12 months) and Phase III (12-18 months). However, production curve trend divides the phase into two; Phase I (5-12 months) and Phase II (1218 months) (Donald et al, 1992; Ciwf.org, 2012; Paly, 2015 and Arifin, 2016). The reason is that hens that lay eggs during mature sexual age (five months) reach peak production quickly then declines as the hen is aging. Therefore, there are two significant trends-rise and fall (Narincet al, 2014; Adam and Bell, 1980; Savegnagoet al, 2012).

The first reason to understand production phase is to make production process efficient by intensifying input utilization; secondly, to decrease the level of amino acid in protein feed 
during the last stage (Phase II) in relation to the high cost of protein feed (Leeson and Summers, 2008). However, obtaining a higher efficiency goes beyond compromising protein level; all inputs must be adjusted according to the ongoing production phase.

Accordingly, it is important to acknowledge the characteristics of egg production phase in laying hens. The study that focused on efficiency without referring to production phase may prove less reliable because the efficiency score is resulted from production phase instead of feed or other inputs. With equal feed or input, hens in Phase I would show better efficiency than that of Phase II, or vice versa.

The study is aimed to analyse the production efficiency and intensity of input use in CSLH according to production phase I and II. The result of the study is expected to contribute to the improved measurement of production efficiency in laying eggs. Furthermore, the study may encourage the farmers to make input adjustment based on the production phase to achieve a more efficient farming venture.

\section{MATERIALS AND METHODS OF RESEARCH}

The study was conducted in South Sulawesi, Indonesia for three months (April - June 2018). The CSLH in the province contains 1000-15000 hens per household. The farmers establish a community named The Community of Household Laying Hen Farmers. The community is collaborating with the provincial government (Department of Livestock and Animal Health) to provide information on livestock breeding technique, animal market and animal health.

Using a survey method, the data were collected from observation, interview with the farmers, documentation and recording. The survey revealed $629 \mathrm{CSLH}$ in the community. Purposive sampling method was applied based on hen's population size and age, concluding a total of 67 samples (10.65\% of the population) consisting of 35 for Phase I and 32 for Phase II. The production phase was determind based on the hens age; 5-12 months for Phase I and 13-18 months for Phase II (Donald et al, 1992, Ciwf.org,2012; Paly, 2015 and Arifin, 2016).

Table 1 - Variables of the study

\begin{tabular}{llll}
\hline Variables & Production Phase I & Production Phase II & Unit \\
\hline Egg production & $\mathrm{Y}_{1}$ & $\mathrm{Y}_{2}$ & $\%$ \\
\hline Main ration & $\mathrm{X}_{11}$ & $\mathrm{X}_{21}$ & IDR \\
\hline Feed additive & $\mathrm{X}_{12}$ & $\mathrm{X}_{22}$ & IDR \\
\hline Labor & $\mathrm{X}_{13}$ & $\mathrm{X}_{23}$ & Hour \\
\hline Experience & $\mathrm{X}_{14}$ & $\mathrm{X}_{24}$ & Year \\
\hline
\end{tabular}

The average egg production was calculated based on the percentage of daily production (\%) in three consecutive months. The main ration (the commercial ration commonly purchased from the agent) was calculated from the average feed intake during the study. The nutrient composition and the price of main ration were different between Phase I and II. Feed additive among farmers were varied in price, brand, form (liquid or solid), ingredients and administration according to the farmers' perception and taste. Therefore, the unit of the two inputs is converted into Indonesian currency (IDR).

The labor unit was hour/day calculated by multiplying the number of labor by the hour of work, and the unit of experience was expressed in year. Labor is considered an important aspect because CSLH required a focused energy and attention. Similarly, the longer the farming experience, the more efficient the farmers work. Therefore, labor and experience are the contributing factors to production efficiency and intensity of input use in this analysis.

Table 2 presents the different composition of main ration between Phase I and II. Nevertheless, the composition was following the National Standard (SNI) 01-3929-1995 on the balanced nutrition for laying hens in Indonesia (SNI, 1995) as well as nutrition expert in laying hens (Leeson and Summers (2008). 
Table 2 - Nutrient content of main ration

\begin{tabular}{llll}
\hline Nutrient & Unit & Production Phase I & Production Phase II \\
\hline Crude protein & $\%$ & $20-22$ & $17-18$ \\
\hline Metabolic energy & $\mathrm{Kcal} / \mathrm{kg}$ & $260-290$ & $280-285$ \\
\hline Calcium & $\%$ & $4-5$ & $4-5$ \\
\hline Phosporus & $\%$ & $0.4-0.50$ & $0.3-0.4$ \\
\hline
\end{tabular}

Source: farmer samples.

Data were subject to Cobb-Douglass production function (CD) analysis usingOrdinary Least Square (OLS) according to Soekartawi (2003)and loanet al(2015). The whole stage of analysis was conducted using SPSS 16 (Ghozali, 2014).

The general model of CD production function is below:

$$
Y=\alpha X^{\beta}
$$

Mathematical model:

$$
Y=\beta_{0} X_{1}^{\beta 1} X_{2}^{\beta 2} \ldots X_{3}^{\beta 3} \ldots X_{4} \beta^{4} \ldots e^{u}
$$

Where $\mathrm{Y}=$ egg production; $\mathrm{X}_{1}$ (main ration); $\mathrm{X}_{2}$ (feed additive); $\mathrm{X}_{3}$ (labor); $\mathrm{X}_{4}$ (experience); $\beta_{1}, \beta_{2}, \beta_{3}, \beta_{4}$ (elasticity coefficient to count); e (disturbance term).

To simplify the estimation, the equation was broadened and converted into linear by natural algorithm (2) (Soekartawi, 2003; Chen 2012).

$$
\operatorname{Ln} Y=\beta_{0}+\beta_{1} \operatorname{Ln} X_{1}+\beta_{2} \operatorname{Ln} X_{2}+\beta_{3} \operatorname{Ln} X_{3}+\beta_{4} \operatorname{Ln} X_{4}+e
$$

The equation of CD production function is different between Production Phase I and II, similar tothe formula byGiyanto (2003) in Marine and Fishery field.

Model forProduction Phase I:

$$
\operatorname{Ln} Y_{1}=\beta_{10}+\beta_{11} \operatorname{LnX} X_{11}+\beta_{2} \operatorname{LnX} 12+\beta_{3 \operatorname{LnX} 13}+\beta_{4 \operatorname{LnX14}}+e
$$

Model forProduction Phase II:

$$
\operatorname{LnY}_{2}=\beta_{20}+\beta_{21} \operatorname{LnX}_{21}+\beta_{22} \operatorname{LnX}_{22}+\beta_{23} \operatorname{LnX} X_{23}+\beta_{4} \operatorname{LnX}_{24}+e
$$

Subscript 1 in equation 4 represents Phase I, Subscript 2 in equation 5 represents Phase II (see Table 1).

Goodness of Fit was statistically tested using R-mutiple, R-squaredand $F$ value (Ghazali, 2014). R-multiple measures the degree of association of all inputs on egg production. The range value of $R$-multiple was $0-1$ where value closer to 1 is more fit (feasible). R-Square $\left(\mathrm{R}^{2}\right)$ shows the percentage of input contribution to production; the higher the value, the more fit (feasible). F statistic is used to evaluate the effect of all inputs on egg production; if $F$ is significant $(p<0.05)$, the input $\left(X_{i}\right)$ in the model is fit (feasible).

Production efficiency was determined by calculating the elasticity coefficient $(\Sigma \beta \mathrm{i})$ in equation 4 and 5 (Soekartawi, 2003). If $\Sigma \beta i>1$, increasing return to scale (IRT) is achieved. However, it is not efficient because a proportional inputincrease $\left(X_{i}\right)$ would result in a higher egg production $\left(\delta \Sigma X_{i} / \delta Y>1\right)$. If $\Sigma \beta i<1$, decreasing return to scale (DRT)is no longer efficient because increasing input $\left(X_{i}\right)$ would result in equal egg production $\left(\delta \Sigma X_{i} / \delta Y<1\right)$. Efficiency is achieved when $\Sigma \beta i=1$ or Constant return to scale because a proportional addition of input $\left(X_{i}\right)$ resulted in equal egg production $\left(\delta \Sigma \mathrm{X}_{\mathrm{i}} / \delta \mathrm{Y}=1\right)$.

Evaluating the intensity of input use is conducted by identifying the partial input elasticity from the equation of $C D$ production function (equation 4 and 5 ). The criteria are underintensive (underutilize) if $\beta \mathrm{i}>1$; intensive if $\beta \mathrm{i}=1$; and overintensive (overutilize) if $\beta \mathrm{i}<1$ (Lau and Yotopoulos, 1971; Soekartawi, 2003). 


\section{RESULTS AND DISCUSSION}

The summary statistics of the inputs for CD production function analysis is presented in Table 3. The average egg production, main ration, feed additive, labor and farming experience in Phase I were higher than those in Phase II. A higher standard deviation of production or input indicates that most of the production or input value arenear the mean value. In contrast, a higher standard deviation shows a significant difference from one farmer to another.

Table 3 - Summary statistics

\begin{tabular}{lllll}
\hline \multirow{2}{*}{ Variable } & Fase I & & Fase II & \\
\cline { 2 - 5 } & Mean & Std Dev. & Mean & Std Dev. \\
\hline Egg production (\%) & 75.21 & 3.106 & 56.09 & 4.713 \\
\hline Main ration (IDR/day) & 635.439 & 79.443 & 575.486 & 65.871 \\
\hline Feed additive (IDR/day) & 74.577 & 13.067 & 72.526 & 18.669 \\
\hline Labor (jam/day) & 24.163 & 2.636 & 23.744 & 2.725 \\
\hline Experience (year) & 5.150 & 2.194 & 5.263 & 2.677 \\
\hline Age of laying hens (month) & 9.250 & 2.411 & 16.770 & 3.723 \\
\hline
\end{tabular}

The test was aimed to investigate the feasibility of regression model to estimate the relation between input variable and egg production variable. The test used $R$-multiple, $R$ squared $\left(R^{2}\right)$ and $F$ statistic values (Table 4$)$.

Table 4 - The Goodness of Fit Model Test

\begin{tabular}{llll}
\hline Statistics & Fase I & Fase II & Keterangan \\
\hline R-multiple & 0.766 & 0.791 & Fit (feasible) \\
\hline R-squared $\left(\mathrm{R}^{2}\right)$ & 0.5867 & 0.6256 & Fit (feasible) \\
\hline $\mathrm{F}$ (p-value) & $0.010^{\star}$ & $0.009^{\star}$ & Fit (feasible) \\
\hline
\end{tabular}

*Significant at $0.05(p<0.05)$.

Table 5 - Production model function for Phase I and II

\begin{tabular}{llllll}
\hline Model & Coef. & Std. Error & $\mathrm{T}$ & P-value & Intensity of input use \\
\hline 1 & 2 & 3 & 4 & 5 & 6 \\
\hline Production Phase I & & & & & \\
\hline Intercept & 61.6 & 7.76 & 7.94 & 0.00 & \\
\hline Main ration $\left(\mathrm{LnX}_{11}\right)$ & 1.11 & 0.13 & 8.87 & 0,01 & Under-intensive \\
\hline Feed additive $\left(\mathrm{LnX}_{12}\right)$ & 0.92 & 0.04 & 24.76 & 0,01 & Intensive \\
\hline Labor $\left(\mathrm{LNX}{ }_{13}\right)$ & 0.43 & 0.05 & 8.33 & 0,03 & Over-intensive \\
\hline Farming experience $\left(\mathrm{X}_{14}\right)$ & 0.61 & 0.06 & 10.91 & 0,22 & Over-intensive \\
\hline Total elasticity $\left(\sum \mathrm{Bj}\right)$ & 3.07 & & & & \\
\hline Production Phase II & & & & & \\
\hline Intercept & 52.6 & 7.02 & 7.49 & 0.00 & \\
\hline Main ration $\left(\mathrm{Ln} \mathrm{X}_{21}\right)$ & 1.18 & 0.43 & 2.74 & 0,01 & Under-intensive \\
\hline Feed additive $\left(\mathrm{X}_{22}\right)$ & 0.38 & 0.15 & 2.53 & 0,01 & Over-intensive \\
\hline Labor $\left(\mathrm{LnX} \mathrm{X}_{23}\right)$ & 0.33 & 0.12 & 2.75 & 0,03 & Over-intensive \\
\hline Farming Experience $\left(\mathrm{LnX}_{24}\right)$ & 0.17 & 0.04 & 4.19 & 0,22 & Over-intensive \\
\hline Total elasticity $\left(\sum \mathrm{Bj}\right)$ & 2.06 & & & & \\
\hline
\end{tabular}

R-multiple measured the association between egg production $(Y)$ and total variable inputs $\left(X_{i}\right)$. R-multiple value in Phase I and II was 0.6 and 0.6 , respectively $(>0.5)$, indicating a strong association (fit). $R$ Square $\left(R^{2}\right)$ value or commonly referred as coefficient determinant measures the contribution of total input $\left(\mathrm{X}_{\mathrm{i}}\right)$ simultaneously to production $(\mathrm{Y})$. $\mathrm{R}^{2}$ value in Phase I and II was $58.67 \%$ and $62.56 \%$, respectively. It shows that the contribution of total input $\left(\mathrm{X}_{\mathrm{i}}\right)$ to egg production in Phase I and II was $58.67 \%$ and $62.56 \%$, respectively, and the rest were explained by other variables excluded in this analysis model. $F$ value was used to investigate the simultaneous effect of total input $\left(\mathrm{X}_{\mathrm{i}}\right)$ on production $(\mathrm{Y})$. $\mathrm{F}$ value of Phase I and II showed a significant effect $(p<0.05)$; therefore, the effect of the sample 
analysis can be applied or generalised to the whole CSLH population in South Sulawesi. The three tests concluded that the model of production function in Phase I and II (Table 5) is fit for the model to estimate production efficiency and intensity of input use in this study.

CD Production Function using the Ordinary Least Square (OLS) technique is the proper model to estimate efficiency and intensity of input use (Soekartawi, 2003; Ghozali, 2014 and loan, et al, 2015). The result of analysis is presented in Table 5.

From coefficient in Table 5 (column 2), the model equation is as follows.

Production Phase I:

$$
\begin{gathered}
Y=61.60 x_{11}^{1.11} x_{12}^{0.92} x_{13}^{0.43} x_{14}^{0.61} \\
\operatorname{Ln} Y=61.60+1.11 \operatorname{Ln} X_{11}+0.92 \operatorname{Ln} X_{12}+0.43 \operatorname{Ln} X_{13}+0.61 \operatorname{Ln} X_{14}=79.558 \\
\text { If } X_{i=1}=1 \text { then } \\
\operatorname{Ln} Y=61.60+1.11(1)+0.92(1)+0.43(1)+0.61(1)=72.67
\end{gathered}
$$

Production Phase II:

$$
\begin{gathered}
Y=52.60 x_{21}^{1.18} x_{22}^{0.38} x_{23}^{0.33} x_{24}^{0.17} \\
\operatorname{Ln} Y=52.60+1.18 \operatorname{Ln} X_{11}+0.38 \operatorname{Ln} X_{22}+0.33 \operatorname{Ln} X_{23}+0.17 \operatorname{Ln} X_{24} \\
\text { If } X_{i=1}=1 \text { then } \\
\operatorname{Ln} Y=52.60+(1.18(1)+0.38(1)+0.33(1)+0.17(1)=54.66
\end{gathered}
$$

Production efficiency explained the association between total input and output (egg production). Analysis result showed that the elasticity of total input $\left(\sum \beta_{\mathrm{i}}\right)$ in production Phase I and II was 3.07 and 2.06, respectively $\left(\sum \beta_{\mathrm{i}}>1\right)$. It showed that the production efficiency in Phase I and II was Increasing Return to Scale (IRS).Accordingly, every $1 \%$ proportional increase of input $\left(X_{i}\right)$ improvedegg production by $3.07 \%$ and $2.06 \%$ in Phase I and II, respectively $(>1 \%)$ or $\delta \mathrm{Xi} / \delta Y>1$. This result was not efficient because input capacity in IRT can be added to increase egg production to optimal level. It is considered efficient if $\sum \beta_{i}=1$ or at Constant Return to Scale (CRT) where proportional addition of $1 \%$ input (Xi) increasedegg productionby $1 \%(\delta \mathrm{Xi} / \delta \mathrm{Y}=1)$.

Previous studies were conducted by Yusuf et al (2007) in Ogun State, Begum et al (2010) in Bangladesh, Ramdhani (2011) in Indonesia, and Doganet al. (2018) in Konya Turkey reported the production efficiency of commercial laying hen at IRT $\left(\sum \beta i>1\right)$. Therefore, the present study conformed the previous findings.

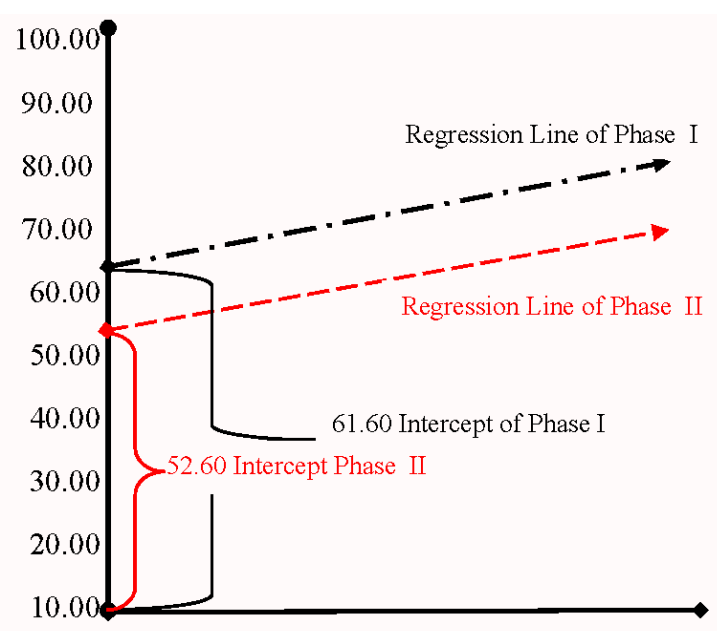

Figure 1. Different Intercept between Phase I and II

Source: Author self-made based on calculation in Table 5

The intercept value of equation 6 and 7 was 61.60 and 52.60, respectively. It shows that egg production value contributed from the total input in Phase I and II during observation was61.60\%, and $52.60 \%$, respectively. If each variable $\left(\mathrm{X}_{11} \ldots \mathrm{X}_{14}\right.$ and $\left.\mathrm{X}_{21} \ldots . \mathrm{X}_{24}\right)$ was 
distributed with the same value (1), the estimated egg production in Phase I and II was $72.62 \%$ and $54.66 \%$, respectively. It was not significantly different from the average production in Table 2. The production gap between the two phases is $18.01 \%$ higher in Phase I (72.67-54.66\%). The different intercept placed the regression line of Phase I higher than Phase II (Figure 1).

Previous studies reported that egg productionin Phase I and II (in respective manner) was $71.20 \%$ and $61.70 \%$ (Donald et al,1992); 80\% and 60\% (Ciwf.org,2012); $75.67 \%$ and $57.17 \%$ (Narincet al, 2014) and $87.45 \%$ and $44.75 \%$ (Arifin, 2016). It indicated a consistenly significant difference in production Phase I and II. Studies showed that in physiological perspective, laying hens' production and reproduction capacity starts to decline at 11-12 months old (Donald et al, 1992, Ciwf.org,2012; Paly, 2015 and Arifin, 2016). The average age of hens in Phase I and II of this study was 9.25 and 16.77 months, respectively (Table 2).Accordingly, it is evidenced that the different intercept in Figure 1 is due to the different Production Phase.

Intensity of input use of Phase I and II in Table 5 is explained in column 6 and visualized in Figure 2 where Production Phase II is signified by the red line. Input elasticity of main ration $\left(\mathrm{X}_{11}\right.$ and $\left.\mathrm{X}_{21}\right)$ in Phase I and II was 1.11 and 1.18 , respectively, because it is within IRT zone or underintensive (underutilizise). Accordingly, $1 \%$ additional input could increase egg production above $1 \%$ or $1.11 \%$ and $1.18 \%$ for Phase I and II, respectively. Feed additive elasticity $\left(\mathrm{X}_{12}\right)$ of Phase I was 0.92 (round up to 1) and Phase II was 0.38 . Feed additive of Phase $I$ is in CRT zone or intensive (optimum), while Phase II is in DRT zone or exceeding the intensive limit (over-intensive). Increasing $1 \%$ feed additive in Phase I would contribute to $0.92 \%$ or $1 \%$ (round up) egg production; however, less contribution was observed in Phase II despite the equal addition (0.38\%). Therefore, the present finding conforms the previous studies (Mohaddes, 2009; Adesiyan and Israel, 2014).

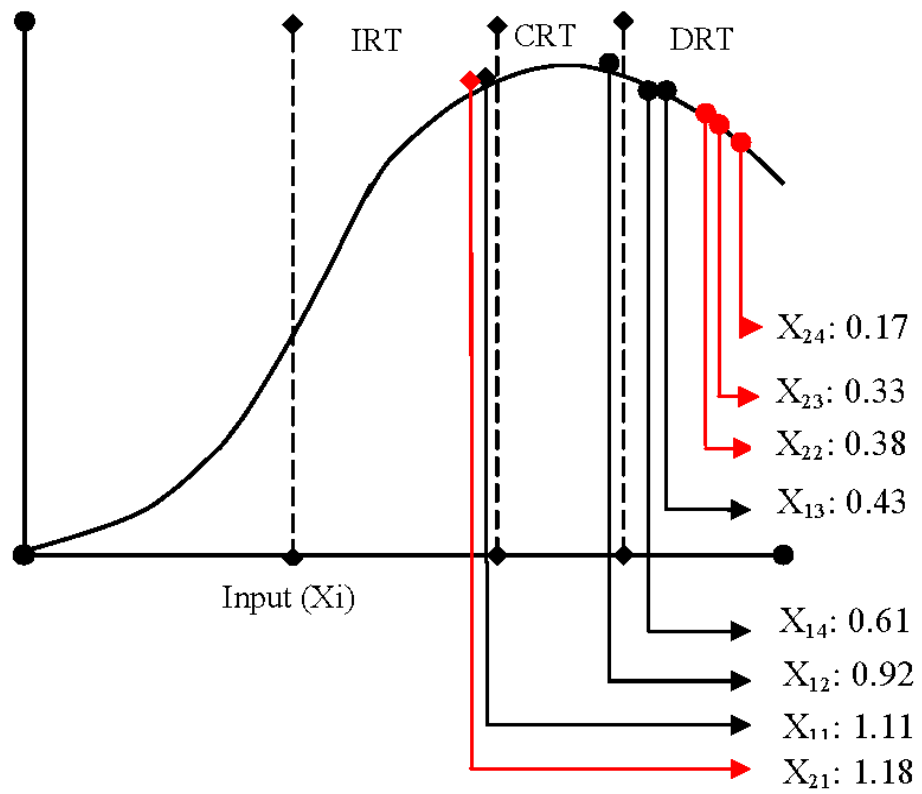

Figure 2. Map of intensity of input use

Source: Author-made according to calculation in Table 5

Labor elasticity $\left(\mathrm{X}_{13} ; \mathrm{X}_{23}\right)$ of Phase I and II in this study was 0.43 and 0.33 , respectively. Therefore, each $1 \%$ additional labor only contributed $0.43 \%$ and $0.33 \%(<1 \%)$ to egg production in Phase I and II, respectively. It indicated that labor input has exceeded intensive limit (over-intensive) or in DRT zone, similar to previous findings (Ramdhani, 2011; Paly, 2015 and Elpawatiet al, 2018).

Experience input $\left(\mathrm{X}_{14} ; \mathrm{X}_{24}\right)$ in Phase I and II was 0.61 and 0.17 , respectively, exceeding the intensive limit (over-intensive) or in DRT zone. Additional $1 \%$ experience input made a 
small contribution to egg production, under $0.61 \%$ and $0.17 \%(<1 \%)$ for Phase I and II, respectively. It conforms the previous findings (Ojo, 2003 and Dogan et al, 2018) who reported experience input in DRT zone, indicating a wastefulness and therefore, suggesting a cut down. It may not be difficult for the farmers because they often reduce or delay buying the unnecessary input in order to prioritize the more important inputs.

\section{CONCLUSION}

The study concluded that the production efficiency in Phase I and II are in Increasing return to scale (IRT) condition. A $1 \%$ proportional increase of total input could increase egg production by $3.07 \%$ and $2.06 \%(>1 \%)$ in Phase I and II, respectively. However, the intercept of production function in Phase I (61.600 was higher than that of Phase II (52.60), resulting in regression line of Phase I above Phase II. The different intercept was due to the different hens' age where Phase II consisted of the laying eggs with average age $16.77 \pm 3.72$ months which experienced a declining production and reproduction capacity.

The intensity of main ration use $\left(X_{11}\right.$ and $\left.X_{21}\right)$ for Phase I and II was under-intensive, and the additional $1 \%$ input could increase egg production by $1.11 \%$ and $1.18 \%(>1 \%)$, respectively. The intensity of feed additive use $\left(X_{12}\right)$ in Phase I is considered optimum (intensive), and additional $1 \%$ input contributed to $1 \%$ of egg production. Phase II showed over-intensive because additional $1 \%$ input only contributed $0.38 \%(<1 \%)$ to egg production.

Intensity of labor $\left(\mathrm{X}_{13} ; \mathrm{X}_{14}\right)$ and experience $\left(\mathrm{X}_{14} ; \mathrm{X}_{24}\right)$ in Phase I and II was overintensive. Additional $1 \%$ input only contributed $<1 \%$ to egg production. Overintensive input was categorized as wasteful input; therefore, it required a cut down from the regular use.

Efficiency of CSLH in Phase I and II could be optimized by increasing main ration input and decreasing labor and experience inputs.

\section{ACKNOWLEDGMENTS}

The author expressed sincerest gratitude to the respondent farmers and the community of commercial smallholder laying egg farmers in South Sulawesi, and the colleagues in Department of Animal Science, Faculty of Science and Technology in Alauddin State Islamic University Makassar, Indonesia for their support in the study.

\section{CONFLICT OF INTERESTS}

The author certifies that he has no "conflict of interest" in the research, from undertaking the field research to writing the manuscript.

\section{REFERENCES}

1. Adams C.J., and Bell D.D. 1980. Predicting Poultry Egg Production.Poultry Science, Vol 59 (4): 937-938, https://doi.org/10.3382/ps.0590937. Accessed on 12 July 2018.

2. Adesiyan O. I and Israel O. 2014. Technical Efficiency of Poultry Production in Afijio Local Government Area of Oyo state, Nigeria. Developing Country Studies, 4 (20): 7480.

3. Arifin H. 2016. Analysis on Different Phases Cycle in Production of Laying Hens. Ghalaza Journal of animal Husbandry (CJAH). Vol. 1(1): 36-41. http://usnsj.com/index.php/CJAH/

4. Begum, Ismat \& Buysse, Jeroen \& Alam, Mohammad \& Van Huylenbroeck, Guido. 2010. Technical, allocative and economic efficiency of commercial poultry farms in Bangladesh. World's Poultry Science Journal. 66. 465 - 476. Accessed on 12 Mey 2018.

5. Chen, Bang-Yen. (2012). Classification of h-homogeneous production functions with constant elasticity of substitution. Tamkang Journal of Mathematics. 43. 10.5556/j.tkjm.43.2012.1145. Accessed on 12 July 2017. 
6. Ciwf.org. 2012. The Life of: Laying hens.Compession in Word Farming:1-6. Farm Animal Welfare Compendium. Available online; https://www.ciwf.org.uk/media/5235024/The-lifeof-laying-hens.pdf. Assecced on 12 May 2018.

7. Dogan N, Kaygisiz F, Altinel A. 2018. Technical and Economic Effciency of Laying Hen Farms in Konya, Turkey. Brazilian Journal of Poultry Science, vol 20 (2): 263-272. http://dx.doi.org/10.1590/1806-9061-2017-0649. Assecced on 14 July 2018

8. Donald D. Bell Carol J. Adams. 1992. First and Second Cycle Egg Production Characteristics in Commercial Table Egg Flocks. Poultry Science, Vol 71 (3): 448-459. https://doi.org/10.3382/ps.0710448. Assecced on 14 July 2018.

9. Elpawati , Bashir Hamman Gabdo, Mohd Mansor Ismail and IImas Abdurofi, 2018. Stochastic Frontier Production Function and Efficiency Status of Poultry Layer Farms in Malaysia. International Journal of Poultry Science, 17: 568-577. DOI: 10.3923/ijps.2018.568.577. Accessed on 15 Mei 2018.

10. Ghazali I. 2014. Ekonometrika; Teori, Konsep and Aplikasi dengan IBM SPSS 22. Semarang, Universitas Diponegoro. Chapter 4,pp 34-37. ISBN: 978-979-704-761-0.

11. Giyanto. 2003. Membandingkan Dua Persamaan Regresi Linear Sederhana. Oseana, Vol XXVIII (1): 19-31. Assecced on 6 Mey 2018.

12. Ioan, Catalin \& Ioan, Gina. (2015). The Complete Theory of Cobb-Douglas Production Function. Acta Universitatis Danubius. Oeconomica. 11: 74-114.

13. Lau L.J and Yotopoulos P.A. 1971. A Test for Relative Efficiency and Application to Indian Agriculture. The American Economic Review, Vol. 61 (1); 94-109. Available. http://www.jstor.org/stable/1910544. Accessed: 12 April 2016.

14. Leeson, S., Summers, J.D. 2008. Commercial Poultry Nutrition, Third Edition, University Books P. O. Box 1326 Guelph, Ontario, Canada N1H 6N8 Nottingham University Press Manor Farm, Church Lane, Thrumpton, Nottingham, NG11 OAX, England, ISBN 978-1904761-78-5 Chapter 4, p 190. Accessed 12 Mey 2018.

15. Mohaddes S.A., 2009. Productivity Analysis of Eggs Production in Khorasan Razavi Province, Iran. International Journal of Poultry Science, 8: 1209-1213.DOI: 10.3923/ijps.2009.1209.1213. Aeccessed on 12 Mey 2018.

16. Narinc, D., Uckardes, F., \& Aslan, E. (2014). Egg production curve analyses in poultry science. World's Poultry Science Journal, 70(4), 817-828. doi:10.1017/S0043933914000877. Accessed on 12 Mey 2018.

17. Ojo S.O. 2003. Productivity and Technical Efficiency of Poultry Egg Production in Nigeria. International Journal of Poultry Science, 2: 459-464. doi 10.3923/ijps.2003.459.464. Accessed on 12 Mey 2018.

Paly, M.B. 2015. The Scale Efeciency and Intensity on the Used on Input at the Second Phase Layer Production. Jurnal Ilmu dan Industri Peternakan, vol. 2 (1): 15-24

18. Ramdhani, Y, 2011. Analisis Skala dan elastisitas Produksi Pendekatan dengan Pendekatan Cobb-Douglas dan Regresi Linear Berganda. Jurnal Teknologi Vol 4 (1):6168. Available online: http://jurtek.akprind.ac.id/sites/default/files/61-68_ramadhani.pdf. Accessed on 17 July 2018.

19. Savegnago, R.P. \& Cruz, Valdecy \& Ramos, Salvador \& Caetano, Stefanya \& Schmidt, G.S. \& Ledur, Monica \& El Faro, L \& Munari, Danisio. (2012). Egg production curve fitting using nonlinear models for selected and nonselected lines of White Leghorn hens. Poultry science, 91: 2977-2987.http://dx.doi.org/10.3382/ps.2012-02277. Accessed on 12 July 2018.

20. SNI (Standard Nasional Indonesia). 1995. Ransum Ayam Ras Petelur (Layer) 01-39291995. Available online: https://jaj066.files.wordpress.com/2008/06/ransum-ayam-raspetelur.pdf. Accessed on 12 Oktober 2018.

21. Soekartawi. 2003. Teori Ekonomi Produksi dengan Pokok Bahasan Analisis Fungsi Cobb Douglas, Chapter 3, pp 44-47. Jakarta, CV Rajawali.

22. Yusuf SA, Malomo O. 2007. Technical effciency of poultry egg production in Ogun State: A data envelopment analysis (DEA) approach. International Journal of Poultry Science 2007; 6(9):622-629. DOI: 10.3923/ijps.2007.622.629. 